\title{
Limnology of rock pools in the river Chenab at Dhoomi, Akhnoor, in Jammu region of the Union Territory of Jammu and Kashmir
}

\author{
S.P.S. Dutta \\ Emeritus Professor, Department of Environmental Sciences, University of Jammu, Jammu \\ (UT), India \\ Email: duttasps@gmail.com
}

\section{Article Info}

https://doi.org/10.31018/ jans.v12i4.2334 Received: August 19, 2020

Revised: November 27, 2020

Accepted: December 4, 2020

\section{How to Cite}

Dutta S.P.S. (2020). Limnology of rock pools in the river Chenab at Dhoomi, Akhnoor, in Jammu region of the Union Territory of Jammu and Kashmir. Journal of Applied and Natural Science, 12(4):599 - 606. https://doi.org/10.31018/jans.v12i4.2334

\begin{abstract}
Small and temporary freshwater rock pools, compared to lakes, ponds and rivers, have received a very little scientific attention in India. For the present limnological study, six rock pools in the river Chenab at Dhoomi, Akhnoor, were analysed seven times for water quality and fauna during 17-01-2011 to 26-01-2011 and have been described. Among various water parameters depth $(6-11 \mathrm{~cm})$, transparency $(6-11 \mathrm{~cm})$ and turbidity $(1.4-6.88 \mathrm{NTU})$ recorded a decrease after high record on first observation. Salinity remained constant $(0.1 \mathrm{ppt})$ on all the seven observations. Dissolved oxygen (DO) observed maximum (12.81 mg/l) record on 19-01-2011 and minimum (9.99 mg/l) on 26-01-2011. Chloride $\left(\mathrm{Cl}^{-}\right)$was minimum $(2.73 \mathrm{mg} / \mathrm{l})$ on 17-01-2011 and 18-012011 and maximum $(6.81 \mathrm{mg} / \mathrm{l})$ on 24-01-2011. Conductivity $\left(75.50-178.8 \mu \mathrm{S} \mathrm{cm}{ }^{-1}\right)$, total dissolved solids (TDS) (40.13 $85.5 \mathrm{mg} / \mathrm{l})$, Biological oxygen demand (BOD) $(2.5-6.63 \mathrm{mg} / \mathrm{l}), \mathrm{pH}(8.26-9.12)$, carbonate $\left(\mathrm{CO}_{3}^{-2}\right)(2.31-22.84 \mathrm{mg} / \mathrm{l})$, bicarbonate $\left(\mathrm{HCO}_{3}{ }^{-}\right)(29.83-71.29 \mathrm{mg} / \mathrm{l})$, calcium $\left(\mathrm{Ca}^{+2}\right)(9.45-29.50 \mathrm{mg} / \mathrm{l})$, magnesium $\left(\mathrm{Mg}^{+2}\right)(2.24-5.38 \mathrm{mg} / \mathrm{l})$, total hardness (TH) $(35.34-95.80 \mathrm{mg} / \mathrm{l})$ and sodium $\left(\mathrm{Na}^{+}\right)(0.44-1.05 \mathrm{mg} / \mathrm{l})$ showed highest record on last observation. Potassium $\left(\mathrm{K}^{+}\right)(0.60$ $-1.70 \mathrm{mg} / \mathrm{l})$ was minimum on 18-01-2011 and maximum on 24-01-2011. Nitrate $\left(\mathrm{NO}_{3}{ }^{-}\right)(0.084-0.373 \mathrm{mg} / \mathrm{l})$, phosphate $\left(\mathrm{PO}_{4}{ }^{3^{-}}\right)$ $(0.043-0.140 \mathrm{mg} / \mathrm{l})$, silicate $\left(\mathrm{SiO}_{4}^{-4}\right)(1.28-3.95 \mathrm{mg} / \mathrm{l})$ and sulphate $\left(\mathrm{SO}_{4}{ }^{-2}\right)(4.89-7.84 \mathrm{mg} / \mathrm{l})$ observed an irregular pulse. Fauna in these rock pools was represented by zooplankton (passive dispersers) belonging to Protozoa ( 27 species), Rotifera (3 species), gemmules of Porifera (2 species) and Turbellaria (1 species) only. Zooplanktonic maximum qualitative record was observed on $6^{\text {th }}$ observation and quantitative on $7^{\text {th }}$ observation. In the absence of any earlier study on freshwater rock pools in the Himalayan rivers, present work shall be of great help for future workers.
\end{abstract}

Keywords: Rockpools, River Chenab, Water quality, Zooplankton

\section{INTRODUCTION}

The name 'Freshwater rockpool' groups all types of depressions that occur on rocky substrata and are found worldwide in all major biomes. Geomorphologically these are similar because they originated from weathering and erosion. The shape and dimensions of rock pools depend on weathering rates and patterns, dictated by local climate and the composition and resistance to erosion of the rock (Campbell, 1997). These rock pools are filled by precipitation, rivers and ground water. The length of inundation period (hydroperiod) averages from a few days to little more than a month (Brendonck et al., 2000). In temperate region, these may remain inundated for several seasons. Rock pools, in general, along the large torrential rivers in the Himalayas are oligotrophic systems with a thin layer of bottom sediments. This is because of regular flushing and renewal of water and removal of bottom sediments by rains and floodwater. The highly variable environmental conditions combined with unpredictable regime require high-stress tolerance of the inhabitants. These temporary water habitats support specialised and moderate number of rare and endemic species (Bratton, 1990; Baskin, 1994, King et al., 1996, Pinder et al., 2000 and Jocque et al., 2007). Fauna in these rock pools is represented by active and passive dispersers and has been reviewed by Jocque et al. (2010) and Alhassan and Hazel (2015). An extensive study by Merlijn et al. (2010) on diversity patterns of freshwater rock pools across the world continents has reported the lowest species diversity in Asian continent which may be due to the paucity of freshwater rock pools studies. In spite of the recent surge of interest in the study of rock pools as model systems for ecological and evolutionary research, having unique habitats, housing a diversity of specialist and endemic species and their importance as sources of fresh water in dry countries, these freshwa- 
ter bodies remain virtually unexplored in India. Shinde and Kulkarni (2020) have done some work on fresh water rock pools in Pune. Taking into consideration the importance of rock pools, supporting unique fauna and lack of studies in Asia, including India, the present study was undertaken on six rock pool clusters in the river Chenab at Dhoomi, Akhnoor, Jammu (U.T.) and was timely and necessary.

\section{MATERIALS AND METHODS}

Topography: The river Chenab, draining Jammu region of the Union territory of Jammu \& Kashmir, is formed by the confluence of Chandra and Bhaga streams at Tandi in Himachal Pradesh. At Panji, at an elevation of 1828 meters above mean sea level, the river enters Jammu region of the Union territory of Jammu and Kashmir. After passing through Kishtwar, Thathri, Doda, Ramban, Reasi, Akhnoor and Pragwal, it enters Pakistan and joins the river Indus near the city of Uch Shariff. Along the sides and in the river Chenab are present rocks having surface pools. For the present limnological studies, six surface rock pools at Dhoomi, Akhnoor, were selected (Figs. 1-8). These rock pools get filled with water during rains and floods and support a good diversity and density of planktonic fauna, which are allogenetic source in the river. These rock pools, in the area of the present study, have a stable environment as the area is under army control, free from anthropogenic interference and irregular flushing and cleaning by rain and river water floods.

Water sampling and analysis: Water samples were collected seven times during 17-01-2011 to 26-012011 in plastic containers. For Dissolve oxygen (DO) and Biological oxygen demand (BOD) water samples were collected in BOD bottles and fixed on the spot. Air and water temperature was recorded using a mercury bulb $\left(\mathrm{C}^{\circ}\right)$ thermometer. Analysis of various water parameters like turbidity (standardised Systronics digital nephalo-turbidity meter, Model 132); pH, electrical conductivity (EC), salinity and dissolved solids (DS) (Century soil/water analysis kit, CMK 731); free carbon dioxide (Free $\mathrm{CO}_{2}$ ) (titrimetric method using sodium hydroxide as titrant and phenolphthalein indicator); dissolved oxygen (Alsterberg's alkaline sodium azide method); BOD (incubating water samples for 5 days at $20^{\circ} \mathrm{C}$ in a BOD incubator); carbonate $\left(\mathrm{CO}_{3}{ }^{-2}\right)$ and bicarbonate $\left(\mathrm{HCO}_{3}{ }^{-}\right)$(sulphuric acid as titrant and phenolphthalein and methyl orange as indicators); chloride $\left(\mathrm{Cl}^{-}\right)$(argentometric titration method using silver nitrate as titrant and potassium chromate indicator); calcium $\left(\mathrm{Ca}^{+2}\right)$; magnesium $\left(\mathrm{Mg}^{+2}\right)$ and total hardness $(\mathrm{TH})$ (EDTA titrant and murexide and Erichrome black $T$ indicators); sodium $\left(\mathrm{Na}^{+}\right)$and potassium $\left(\mathrm{K}^{+}\right)$(Esico microprocessor flame photometer, Model 1382) and phosphate $\left(\mathrm{PO}_{4}{ }^{3^{-}}\right)$(stannous chloride - ammonium molybdate method), silicate $\left(\mathrm{SiO}_{4}{ }^{-4}\right)$ (molybdosilicate method), nitrate $\left(\mathrm{NO}_{3}{ }^{-}\right)$(phenoldisulphonic acid method) and sulphate $\left(\mathrm{SO}_{4}^{-2}\right)$ (turbidimetric method) using
ESICO standardised microprocessor double beam UV-Vis Spectrophotometer, Model 1371, was done within 1 hour of sampling following standard methods (Trivedi et al., 1987 and APHA, 1998).

Zooplankton sampling and analysis: For the zooplanktonic study, $140 \mathrm{ml}$ of water sample was collected from each pool, filtered through a planktonic net (No. 25) and identified (Nair et al., 1971; Pennak, 1978; Dutta, 1983; Kudo, 1986; Battish, 1992 and Edmondson, 1992). For quantitative planktonic analysis, Sedgewick rafter counting cell was used. The results of seven observations are tabulated as the mean of six rock pools.

\section{RESULTS AND DISCUSSION}

Physico-chemical characteristics of water: The mean results of various physicochemical characteristics of water in six rock pools of the river Chenab, analysed during 7 days, are given in Table 1 .

Air temperature in the area varied between $13^{\circ} \mathrm{C}\left(3^{\text {rd }}\right.$ observation on 19-01-2011) to $20^{\circ} \mathrm{C}$ (last observation on 26-01-2011). Due to shallowness and penetration of sunlight and heating of water up to the bottom, water temperature closely followed the air temperature and fluctuated between $11.33^{\circ} \mathrm{C}\left(3^{\text {rd }}\right.$ observation on 19-01-2011) to $19^{\circ} \mathrm{C}$ ( final observation on 26-012011). Both air and water temperature showed a difference of $7^{\circ} \mathrm{C}$ and $7.67^{\circ} \mathrm{C}$, respectively (Table 1 ). Water temperature in rock pools depends on climate and maxima have been shown to vary from $32^{\circ} \mathrm{C}$ in Finland (Ganning, 1971), $35^{\circ} \mathrm{C}$ in Utah (Scholnick, 1994) to over $40^{\circ} \mathrm{C}$ in Botswana (Brendonck et al., 2000).

Depth and transparency, mean analysis in these shallow pools, recorded a gradual decrease from first to the last observation and both varied between $11.0 \mathrm{~cm}$ (17-01-2011) to $6 \mathrm{~cm}$ (26-01-2011). This change is attributed to water evaporation in the absence of any rain or floodwater from the river during the period of the present analysis.

Turbidity was maximum (6.88 NTU) on the first day of observation (17-01-2011). It recorded a gradual decrease, due to sedimentation of suspended matter, and showed minimum mean observation of 1.4 NTU on 24-01-2011 and 26-01-2011. It recorded a difference of 5.48 NTU.

Water in these pools remained alkaline. $\mathrm{pH}$ showed a gradual increase after a minimum mean value of 8.26 on 17-01-2011 to a maximum value of 9.12 on $26-01$ 2011. The rise in $\mathrm{pH}$ coincided with a gradual increase in $\mathrm{CO}_{3}{ }^{-2}$. The latter varied between $2.31 \mathrm{mg} / \mathrm{l}$ (17-01$2011)$ to $22.84 \mathrm{mg} / \mathrm{l}(26-01-2011)$. This reveals a direct relationship between $\mathrm{pH}$ and $\mathrm{CO}_{3}^{-2}$ (Welch, 1952; Reid and Wood, 1976 and Wetzel, 2000). $\mathrm{HCO}_{3}{ }^{-}$recorded minimum (29.83 mg/l) observation on 19-012011 and the maximum (71.29 mg/l) on 26-01-2011. $\mathrm{pH}, \mathrm{CO}_{3}{ }^{-2}$ and bicarbonate, recorded a difference of 0.86, $20.53 \mathrm{mg} / \mathrm{l}$ and $41.46 \mathrm{mg} / \mathrm{l}$, respectively (Table 1). 


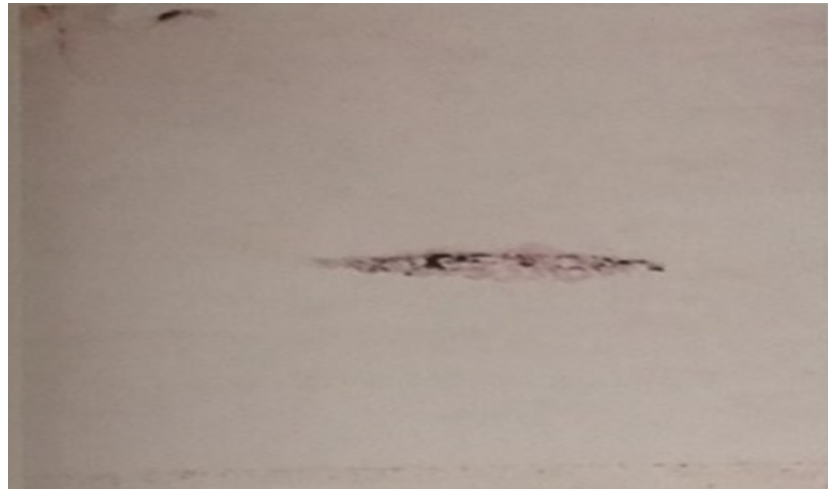

Fig. 1. Rocks in the river Chenab during floods.

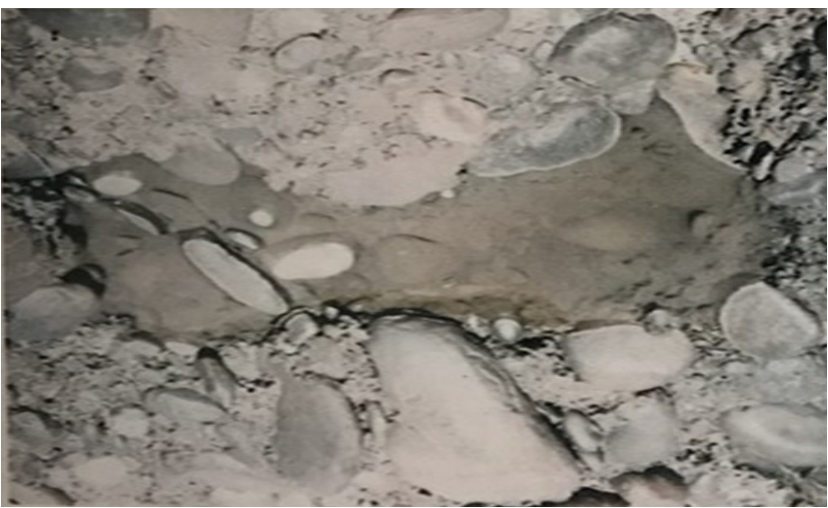

Fig. 3. General view of rock pool 1.

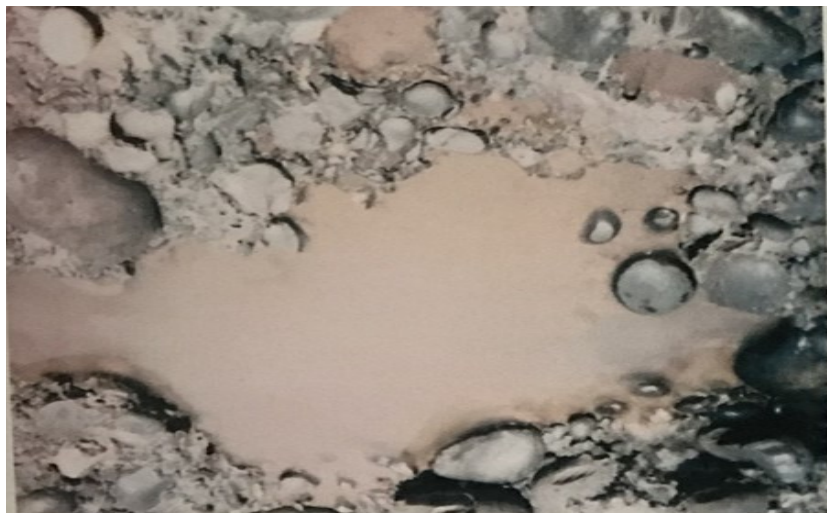

Fig. 5. General view of rock pool 3.

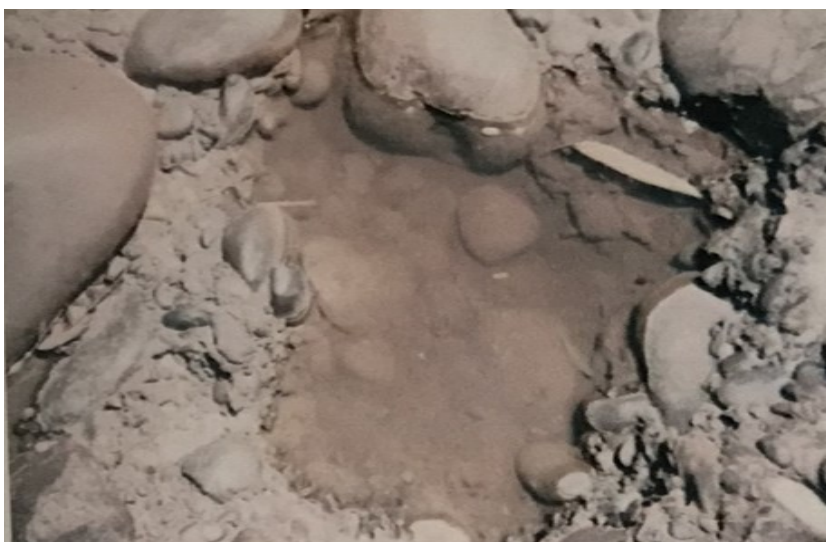

Fig. 7. General view of rock pool 5.

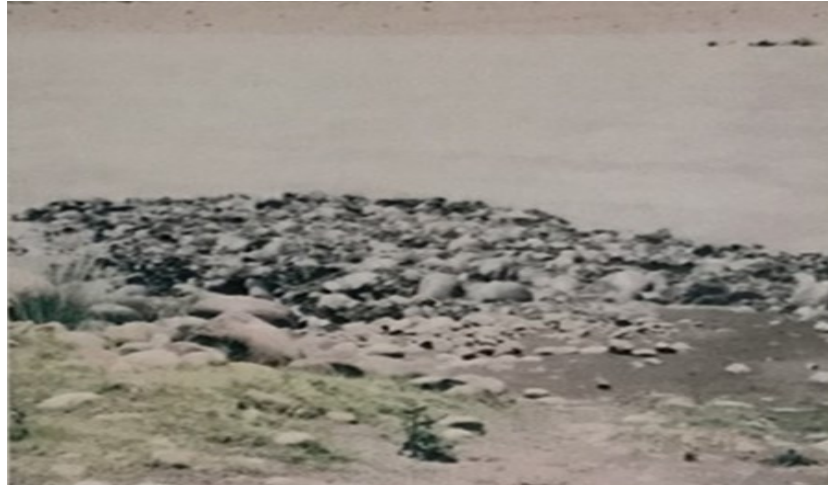

Fig. 2. Rocks in the river Chenab during winter

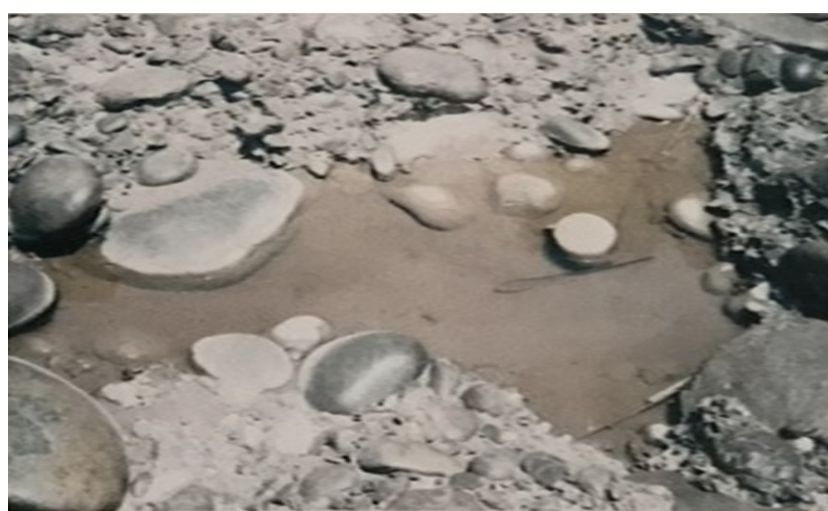

Fig. 4. General view of rock pool 2.

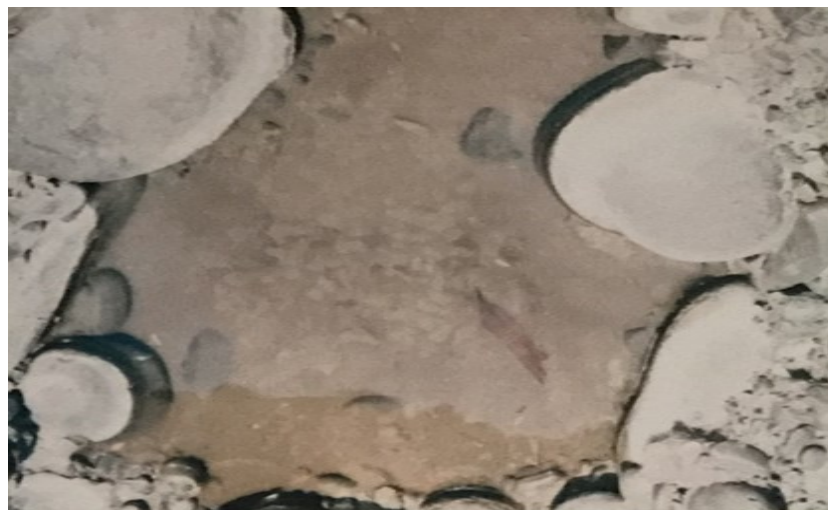

Fig. 6. General view of rock pool 4.

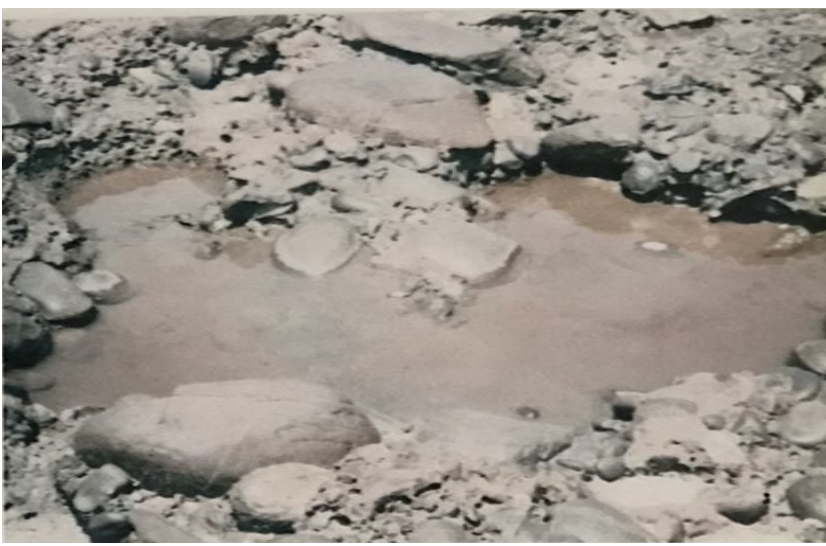

Fig. 8. General view of rock pool 6.

Plate I (Figs. 1-8). Showing general view of the river Chenab and rock pools at Dhoomi, Akhnoor, Jammu. 
Table 1. Mean of seven observations on physicochemical characteristics of water in six rock pools on the left bank of the River Chenab at Dhoomi, Akhnoor, Jammu (17-01-2011 - 26-01-2011).

\begin{tabular}{|c|c|c|c|c|c|c|c|}
\hline Dated & 17 & 18 & 19 & 20 & 21 & 24 & 26 \\
\hline \multicolumn{8}{|l|}{ Parameters } \\
\hline Air temp $\left(C^{\circ}\right)$ & 17 & 15 & 13 & 14 & 16 & 19 & 20 \\
\hline Water temp. $\left(\mathrm{C}^{\circ}\right)$ & 12.33 & 13.83 & 11.33 & 11.50 & 13.83 & 14.50 & 19.00 \\
\hline Depth (Cm) & 11.00 & 9.67 & 9 & 7.5 & 6.5 & 8 & 6 \\
\hline Transparency $(\mathrm{Cm})$ & 11.00 & 9.67 & 9 & 7.5 & 6.5 & 8 & 6 \\
\hline Turbidity (NTU) & 6.88 & 5.45 & 5.05 & 3.53 & 3.00 & 1.4 & 1.4 \\
\hline $\mathrm{pH}$ & 8.26 & 8.30 & 8.59 & 8.51 & 8.54 & 8.92 & 9.12 \\
\hline Conductivity $\left(\mu \mathrm{S} \mathrm{cm}^{-1}\right)$ & 92.5 & 81.00 & 96.12 & 80.66 & 75.50 & 144.3 & 178.8 \\
\hline TDS (mg/l) & 45.35 & 40.13 & 47.02 & 45.83 & 61.88 & 68.3 & 85.5 \\
\hline Salinity (ppt) & 0.1 & 0.1 & 0.1 & 0.1 & 0.1 & 01 & 01 \\
\hline DO (mg/l) & 12.74 & 12.14 & 12.81 & 11.97 & 12.47 & 12.31 & 9.99 \\
\hline $\mathrm{BOD}(\mathrm{mg} / \mathrm{l})$ & 2.5 & 3.36 & 3.88 & 2.54 & 2.67 & 6.20 & 6.63 \\
\hline Free $\mathrm{CO}_{2}(\mathrm{mg} / \mathrm{l})$ & Absent & Absent & Absent & Absent & Absent & Absent & Absent \\
\hline $\mathrm{CO}_{3}^{-2}(\mathrm{mg} / \mathrm{l})$ & 2.31 & 2.92 & 4.46 & 6.30 & 7.47 & 11.07 & 22.84 \\
\hline $\mathrm{HCO}_{3}{ }^{-}(\mathrm{mg} / \mathrm{l})$ & 30.95 & 31.68 & 29.83 & 42.52 & 34.97 & 41.27 & 71.29 \\
\hline $\mathrm{Cl}^{-}(\mathrm{mg} / \mathrm{l})$ & 2.73 & 2.73 & 2.93 & 5.46 & 5.45 & 6.81 & 6.06 \\
\hline $\mathrm{Ca}^{+2}(\mathrm{mg} / \mathrm{l})$ & 11.04 & 9.45 & 12.47 & 15.79 & 22.17 & 25.95 & 29.50 \\
\hline $\mathrm{Mg}^{+2}(\mathrm{mg} / \mathrm{l})$ & 2.24 & 2.85 & 3.93 & 4.47 & 3.71 & 4.30 & 5.38 \\
\hline $\mathrm{TH}(\mathrm{mg} / \mathrm{l})$ & 36.75 & 35.34 & 47.87 & 57.77 & 70.95 & 82.39 & 95.80 \\
\hline $\mathrm{Na}^{+}(\mathrm{mg} / \mathrm{l})$ & 0.60 & 0.44 & 0.79 & 0.78 & 0.87 & 0.88 & 1.05 \\
\hline $\mathrm{K}^{+}(\mathrm{mg} / \mathrm{l})$ & 0.77 & 0.60 & 0.64 & 0.67 & 0.90 & 1.70 & 1.08 \\
\hline $\mathrm{PO}_{4}{ }^{3^{-}}(\mathrm{mg} / \mathrm{l})$ & 0.050 & 0.086 & .133 & 0.054 & .043 & .140 & .114 \\
\hline $\mathrm{NO}_{3}^{-}(\mathrm{mg} / \mathrm{l})$ & 0.373 & .245 & .084 & .137 & .209 & .242 & 0.220 \\
\hline $\mathrm{SiO}_{4}^{-4}(\mathrm{mg} / \mathrm{l})$ & 1.28 & 1.39 & 3.95 & 1.63 & 1.58 & 2.37 & 3.91 \\
\hline $\mathrm{SO}_{4}^{-2}(\mathrm{mg} / \mathrm{l})$ & 7.05 & 4.93 & 4.89 & 7.84 & 5.83 & 6.81 & 7.07 \\
\hline
\end{tabular}

Due to the presence of $\mathrm{CO}_{3}^{-2}$ on all the observations, free $\mathrm{CO}_{2}$ remained absent, and this supports an inverse relationship between these two parameters (Reid \& Wood, 1976 and Wetzel, 2000).

Total dissolved solids (TDS) in these shallow rock pools varied from a minimum of $40.13 \mathrm{mg} / \mathrm{l}$ (18-01$2011)$ to a maximum of $85.5 \mathrm{mg} / \mathrm{l}$ (26-01-2011). Conductivity recorded maximum record of $178.8 \mu \mathrm{S} \mathrm{cm}^{-1}$ and a minimum of $75.50 \mu \mathrm{Sm}^{-1}$ on 26-01-2011 and 21-01-2011, respectively, in these pools. Maximum record of conductivity and TDS on last observation coincided with the highest record of $\mathrm{CO}_{3}{ }^{-2}, \mathrm{HCO}_{3}{ }^{-}$, $\mathrm{Ca}^{+2}, \mathrm{Mg}^{+2}, \mathrm{TH}$ and $\mathrm{Na}^{+}$(Table 1). According to Jocque et al. (2010) rock pools are characterized by low conductivity after filing. As the water evaporates, the conductivity increases mainly because of the metabolites.

Salinity remained constant at $0.1 \mathrm{ppt}$ from first to the last observation and may be due to low record of various cations and anions.
DO, mean analysis of six pools, was minimum (9.99 $\mathrm{mg} / \mathrm{l})$ on last observation and maximum (12.81 $\mathrm{mg} / \mathrm{l})$ on $3^{\text {rd }}$ observation. Oxygen remained high during the first few observations and is related to the agitation of rainwater, after falling and moving on hard rocks, and comparatively low temperature. Minimum record of DO in these pools was on last observation and coincided with the highest record in temperature $\left(19^{\circ} \mathrm{C}\right)$. An inverse relationship of oxygen solubility with temperature is well explained by Naseema et al. (2013) at different ghats of the river Ganga, Kanpur; Dutta (2014) in Devak stream in Udhampur, Jammu; Aggarwal (2016) from Shahpur lake, Bhopal and Bhutiani et al.(2017) in Hindon River (NCR), Uttar Pradesh.

BOD in these rock pools varied between $2.5 \mathrm{mg} / \mathrm{l}$ (1701-2011) to $6.63 \mathrm{mg} / \mathrm{l}$ (26-01-2011). A narrow variation in BOD (4.13 mg/l) coincided with low quantity of dead organic matter in water suspension and on bottom of these rock pools.

$\mathrm{Cl}^{-}$in these shallow rock pools fluctuated between 
$2.73 \mathrm{mg} / \mathrm{l}$ (16 and 17-01-2011) to $6.81 \mathrm{mg} / \mathrm{l}$ (24-012011) and observed a difference of $4.08 \mathrm{mg} / \mathrm{l}$.

$\mathrm{Ca}^{+2}, \mathrm{Mg}^{+2}$ and $\mathrm{TH}$ showed a mean variation of 9.45 (18-01-2011) -29.50 mg/l (26-01-2011), 2.24 (17-012011) $-5.38 \mathrm{mg} / \mathrm{l}(26-01-2011)$ and 35.34 (18-01-2011) - $95.80 \mathrm{mg} / \mathrm{l}$ (26-01-2011), respectively. These recorded minimum observation on $1^{\text {st }} / 2^{\text {nd }}$ observation and maximum on final observation (Table 1). $\mathrm{Ca}^{+2}$, $\mathrm{Mg}^{+2}$ and $\mathrm{TH}$ observed a difference of $20.05 \mathrm{mg} / \mathrm{l}, 3.14$ $\mathrm{mg} / \mathrm{l}$ and $60.46 \mathrm{mg} / \mathrm{l}$, respectively, in these rock pools (Table 1).

$\mathrm{Na}^{+}$observed minimum mean record of $0.44 \mathrm{mg} / \mathrm{l}$ on 18-01-2011 and maximum of $1.05 \mathrm{mg} / \mathrm{l}$ on 26-012011. $\mathrm{K}^{+}$showed minimum value of $0.60 \mathrm{mg} / \mathrm{l}(18-01-$ 2011) and maximum of $1.70 \mathrm{mg} / \mathrm{l}(24-01-2011) . \mathrm{Na}^{+}$ and $\mathrm{K}^{+}$showed a difference of $0.61 \mathrm{mg} / \mathrm{l}$ and $1.1 \mathrm{mg} / \mathrm{l}$, respectively, in these shallow rock pools.

$\mathrm{PO} \square^{3} \square$ in these rock pools varied between $0.050 \mathrm{mg} / \mathrm{l}$ (17-01-2011) to $0.140 \mathrm{mg} / \mathrm{l}$ (24-01-2011). $\mathrm{NO}_{3}{ }^{-}$recorded minimum observations of $0.084 \mathrm{mg} / \mathrm{l}$ (19-01-2011) and a maximum of $0.373 \mathrm{mg} / \mathrm{l}$ (17-01-2011). A maximum record of $\mathrm{NO}_{3}{ }^{-}$on first observation may be due to the effect of $\mathrm{NO}_{3}{ }^{-}$enriched rainwater. Jocque et al. (2010) also reported high nitrogen in water immediately after filling of pools. Minimum (1.28 mg/l) record of $\mathrm{SiO}_{4}^{-4}$ in these rock pools is seen on 17-01-2011 and maximum (3.95 mg/l) on 19-01-2011. $\mathrm{SO}_{4}^{-2}$ showed a maximum value of $7.84 \mathrm{mg} / \mathrm{l}$ and minimum of $4.89 \mathrm{mg} /$ I on 20-01-2011 and 19-01-2011, respectively. (Table 1).

Due to poor biotic diversity (producers and consumers), low deposits of dead organic matter and absence of human interference, various water quality parameters in these pools recorded a narrow variation.

In the month of January, records of various physicochemical parameters of water viz. air temperature $\left(18^{\circ} \mathrm{c}\right)$, water temperature $\left(8^{\circ} \mathrm{c}\right)$, turbidity (28.05 NTU), transparency $(150 \mathrm{~cm}), \mathrm{pH}(8.27)$, conductivity (305 $\left.\mu S \mathrm{~cm}^{-1}\right)$, TDS (154.35 mg/l), salinity (0.2 ppt), DO (13.32 mg/l), BOD (1.5 mg/l), $\mathrm{CO}_{3}^{-2}$ (3.69 mg/l), $\mathrm{HCO}_{3}^{-}$ (69.41 mg/l), Cl- $(6.47 \mathrm{mg} / \mathrm{l}), \mathrm{Ca}^{+2}(31.90 \mathrm{mg} / \mathrm{l}), \mathrm{Mg}^{+2}$ (10.38 mg/l), TH (122.32 mg/l), $\mathrm{Na}^{+}(1.46 \mathrm{mg} / \mathrm{l}), \mathrm{K}^{+}$ (1.27 mg/l), $\mathrm{PO}_{4}^{3^{-}}(0.029 \mathrm{mg} / \mathrm{l}), \mathrm{NO}_{3}{ }^{-}(0.267 \mathrm{mg} / \mathrm{l})$, $\mathrm{SiO}_{4}^{-4}(6.02 \mathrm{mg} / \mathrm{l})$ and $\mathrm{SO}_{4}^{-2}(20.38 \mathrm{mg} / \mathrm{l})$ in the river Chenab are different from these pools and reveals absence of any type of effect of riverine water on the water quality of these pools during the period of present analysis.

Rock pools fauna: Jocque et al. (2010) reviewed works on faunal diversity of freshwater rock pools and enlisted 460 species, excluding Rotifera, Hydrachnida and Protozoa, worldwide and categorized 213 species as passive dispersers (large branchiopods, Cladocera, Copepoda, Ostracoda and miscellaneous) and 247 species as active dispersers (Diptera, Hemiptera, Coleoptera, Odonata and Anura). Shinde and Kulkarni (2020) noticed insects crustaceans and tardigrades from freshwater rock pools in Pune, India. Present faunal analysis in six rock pools of the river Chenab showed the presence of zooplankton belonging to Protozoa, Rotifera, Turbellaria and gemmules of freshwater sponges only. Earlier, Lane (1978) and Williams (1997) documented the presence of zooplankton belonging to protozoans, rotifers, cladocerans and copepods inhabiting freshwater rock pools. Tavernini (2008), Pinder et al. (2000), Anusa et al. (2012) and Alhassan and Hazel (2015) enlisted zooplankton belonging to rotifers, cladocerans and copepods in freshwater rock pools.

Poor faunal diversity in rock pools of the river Chenab, under discussion, was due to shallowness, short hydroperiod, irregular flushing by floods in the river and rainwater and absence of aquatic vegetation. According to Jocque et al., 2007 and Vanschoenwinkel et al., 2009 , rock pools with longer hydroperiod tend to have a higher diversity of invertebrates. Moreover, there was a low faunal diversity in the river Chenab and was represented by protozoans, gemmules of freshwater sponges and turbellarians only (Dutta, 2012).

Qualitative composition and quantitative analysis of zooplankton: The mean results of qualitative composition and quantitative analysis of zooplankton in six surface rock pools of the river Chenab at Dhoomi, Akhnoor, are tabulated in Table2.

Qualitative composition: Qualitatively, zooplankton, comprising of 33 species, has shown the presence of 27 species of Protozoa(Arcella vulgaris, A. discoides, Centropyxis ecornis, C. aculeata, C. aerophila, C. constricta, C. arcelloides, Difflugia tuberculata, D. acuminata, $D$. lebes, $D$. oblonga, $D$. corona, $D$. bacillifera, $D$. urceolata, D. rusbescens, Difflugia sp., Lesquersia modesta, L. spiralis, Cucurbitella sp., Nebela sp., Euglena sp., Phacus sp., Paramecium sp., Chilodonella $s p$. Euplotes sp., Stylonychia $s p$.and Vorticella $s p),$. species of Rotifera (Lepadella sp., Philodina sp. and Rotaria sp.), gemmules of 2 species of Porifera (Spongilla lacustris and Eunapius carteri) and one species of Turbellaria (Planaria sp.).

Among protozoans, the most dominant group, there is a dominance of Rhizopoda (20 species) followed by Ciliata( 5 species) and Mastigophora ( 2 species). Among various genera of Rhizopoda the order of qualitative dominance has been observed as Diffugia(9 species) >Centropyxis (5 species) > Lesquersia and Arcella ( 2 species, each) and Cucurbitella sp. and Nebela sp (1 species, each). Rhizopods in water samples were represented mostly by shells. Class Mastigophora is represented by Euglena and Phacus genera. Paramecium, Chilodonella, Vorticella, Euplotes and Stylonychia are the genera of class Ciliata seen in these rock pools (Table 2 ).

On the first observation viz. 17-01-2011 only five species of Diffugia, 1 species of Lesquersia and gemmules of Spongilla lacustris were seen in planktonic samples analysed Zooplankton sampled and analysed on 18-01-2011 showed seven species of Diffugia, 2 species of Lesquersia and one species of Cucurbitella, 
Table 2. Mean qualitative composition and quantitative analysis $(n / l)$ of zooplankton, based on seven observations, in six rock pools on the left bank of the River Chenab at Dhoomi, Akhnoor Jammu (17-01-2011 to 26-01-2011).

\begin{tabular}{|c|c|c|c|c|c|c|c|}
\hline Dated & 17 & 18 & 19 & 20 & 21 & 24 & 26 \\
\hline $\begin{array}{l}\text { Protozoa } \\
\text { Sarcodina } \\
\text { Rhizophoda }\end{array}$ & & & & & & & \\
\hline Arcella discoides Ehrenberg & - & - & - & 1 & 5 & 7 & 14 \\
\hline A. vulgaris Ehrenberg & - & - & - & 1 & 13 & 14 & 7 \\
\hline Total Arcella & - & - & - & 2 & 18 & 21 & 21 \\
\hline Centropyxis ecornis Ehrenberg & - & - & - & - & 4 & 14 & - \\
\hline C. aculeata Ehrenberg & - & - & - & - & 1 & 7 & 21 \\
\hline C. aerophila Deflander & - & - & - & - & 1 & - & 21 \\
\hline C. constricta Penard & - & - & - & - & 1 & 42 & 7 \\
\hline C. arcelloides Penard & - & - & - & - & 2 & 7 & 21 \\
\hline Total Centropyxis & - & - & - & - & 9 & 70 & 70 \\
\hline Difflugia tuberculata Wallich & 1 & 6 & 1 & - & 6 & 14 & - \\
\hline D. acuminata Ehrenberg & 5 & 8 & 5 & 5 & 5 & 7 & 42 \\
\hline D. lebes Penard & - & - & - & - & 5 & 7 & 35 \\
\hline D. oblonga Ehrenberg & 7 & 18 & 7 & 8 & 18 & 21 & 14 \\
\hline D. corona Wallich & 2 & - & 2 & 2 & 6 & 14 & - \\
\hline D urceolata Carter & - & 4 & - & - & 5 & 7 & - \\
\hline D. bacillifera Penard & - & 2 & 2 & - & 1 & 7 & 7 \\
\hline D. rubescens Penard & - & 2 & - & - & 1 & 14 & 14 \\
\hline Difflugia $s p$. & 2 & 1 & 2 & 1 & 1 & 7 & 21 \\
\hline Total Difflugia & 17 & 41 & 19 & 16 & 48 & 98 & 133 \\
\hline Lesquereusia modesta Rhumbler & 4 & 1 & - & 2 & 2 & 7 & 14 \\
\hline L. spiralis Ehrenberg & & 2 & & 4 & - & 7 & 7 \\
\hline Total Lesquereusia & 4 & 3 & - & 6 & 2 & 14 & 21 \\
\hline Cucurbitella Penard & - & 2 & 2 & - & - & 7 & 7 \\
\hline Nebela Leidy & - & 2 & 2 & - & - & - & - \\
\hline $\begin{array}{l}\text { Total Rhizophoda } \\
\text { Mastigophora }\end{array}$ & 21 & 51 & 23 & 22 & 50 & 210 & 252 \\
\hline Euglena Ehrenberg & - & - & - & - & - & 42 & 7 \\
\hline Phacus Dujardin & - & - & - & - & - & 7 & 14 \\
\hline Total Mastigophora & - & - & - & - & - & 49 & 21 \\
\hline \multicolumn{8}{|l|}{ Ciliata } \\
\hline Paramecium Hill & - & - & - & 1 & 4 & 56 & 14 \\
\hline Chilodonella Strand & - & - & - & - & 1 & 14 & \\
\hline Vorticella Linnaeus & - & - & - & - & 1 & 7 & 14 \\
\hline Euploteus Ehrenberg & - & - & - & - & 2 & 14 & 21 \\
\hline Stylonychia Ehrenberg & - & - & - & - & 2 & 14 & 56 \\
\hline Total Ciliata & - & - & - & - & 10 & 105 & 105 \\
\hline Total Protozoa & 21 & 51 & 23 & 23 & 87 & 364 & 378 \\
\hline \multicolumn{8}{|l|}{ Porifera } \\
\hline Spongilla lacustris Linnaeus & 1 & 1 & 4 & - & 1 & - & 14 \\
\hline Eunapius carteri Carter & - & - & - & & 1 & - & \\
\hline $\begin{array}{l}\text { Total Porifera } \\
\text { Rotifera }\end{array}$ & \multicolumn{6}{|c|}{ Rotifera } & 14 \\
\hline Lepadella Boryde St. Vincent & - & - & - & - & 2 & 14 & 7 \\
\hline Philodina Ehrenberg & - & - & - & - & 4 & 7 & 28 \\
\hline Rotaria Scopoli & - & - & - & - & 7 & 7 & 14 \\
\hline Total Rotifera & - & - & - & - & 13 & 28 & 49 \\
\hline \multicolumn{8}{|l|}{ Turbellaria } \\
\hline Planaria Kenk & - & - & - & 6 & 1 & 21 & 7 \\
\hline Total zooplankton & 22 & 52 & 27 & 29 & 103 & 413 & 448 \\
\hline
\end{tabular}

Nebela and gemmules of Spongilla lacustris. During third sampling day viz. 19-01-2011 only six species of Diffugia and one species of Cucurbitella sp, Nebela $\mathrm{sp}$ and gemmules of Spongilla lacustris made their presence. Two species of Arcella, four species of Diffugia, two species of Lesquersia and one species of Paramecium and Planaria showed their presence among zooplanktonic samples on 20-01-2011. There was sudden increase in qualitative zooplanktonic diversity on 21-01-2011, when 2 species of Arcella. 5 species of Centropyxis, 9 species of Diffugia, 1 species of Lesquersia, 5 species of Ciliata, 2 species of Porif- 
era, 3 species of Rotifera and 1 species of Planaria made their records among zooplanktonic samples. Zooplankton recorded maximum diversity on 24-012011 and was shared by 2 species of Arcella, 4 species of Centropyxis, 9 species of Difflugia, 2 species of Lesquersia and 1 species of Cucurbitella, Euglena, Phacus, Paramecium, Chilodonella, Vorticella, Euplotes, Stylonychia, Lepadella, Philodina, Rotaria and Planaria among planktonic samples in these rock pools. On $26^{\text {th }}$ January 2011 zooplanktonic diversity showed a little decline and was represented by 2 species of Arcella, 4 species of Centropyxis, 6 species of Difflugia, 2 species of Lesquersia and 1 species of Cucurbitella, 2 species of Mastigophora (Euglena and Phacus), 4 species of Cilliata (Paramecium, Vorticella, Euploteus and Stylonychia), 3 species of Rotifera (Lepadella, Philodina and Rotaria) and 1 species of Turbellaria (Planaria) and Porifera (Spongilla lacustris).

In the river Chenab, 28 species of zooplankton belonging to 25 species of Protozoa, 2 species of Porifera and one species of Turbellaria have been recorded (Dutta, 2012). When compared with 33 species of zooplankton in these rock pools, it is clear that zooplankton was less diverse in the river Chenab. Among ciliate protozoans Chilodenella, Vorticella, Euploteus and Stylonychia observed in rock pools are absent in the river. Rotifers are restricted to these rock pools only. A rich zooplanktonic diversity in these rock pools may be due to: i) lentic conditions,ii) shallowness, iii) transparent water and penetration of light upto the bottom, iv) low turbidity, v) comparatively warm water, vi) presence of soft sediments mixed with organic matter.

This study clearly supports that zooplankton origin in the torrential river Chenab is also in these rock pools and are carried to the main river during floods and overflow of water along with rains.

A very important question is the survival of zooplankton in these rock pools during unfavourable dry conditions. Protozoans encyst during unfavourable dry conditions (Kudo, 1986) and rotifers and planarians produce resting eggs (Edmondson, 1992 and Jocque et al., 2010). After filling of these pools with water, zooplankton hatch from various resting stages and start appearing during different dates among planktonic samples

Quantitative analysis: The study has revealed a gradual increase in zooplanktonic count from $1^{\text {st }}$ observation on 17-01-2011 to $7^{\text {th }}$ observation on 26-012011(Table 2). This might be due to hatching of resting stages at different times, after filling of pools by rain water, and increased concentration with fall in water depth.

Total zooplanktonic analysis in these six pools on first, second, third, fourth, fifth, sixth and seventh observation has shown a mean record of $22 \mathrm{n} / \mathrm{l}, 52 \mathrm{n} / \mathrm{l}, 27 \mathrm{n} / \mathrm{l}$, 29 n/l, 103 n/l, 413 n/l and 448 n/l, respectively. On all the observations there is dominance of protozoans with a mean record of $21 \mathrm{n} / \mathrm{l}, 51 \mathrm{n} / \mathrm{l}, 23 \mathrm{n} / \mathrm{l}, 23 \mathrm{n} / \mathrm{l}, 87 \mathrm{n} /$ I, $364 \mathrm{n} / \mathrm{l}$ and $378 \mathrm{n} / \mathrm{l}$, respectively. Porifera showed their presence on first $(1 \mathrm{n} / \mathrm{l})$, second $(1 \mathrm{n} / \mathrm{l})$, third $(4 \mathrm{n} /$ I), fifth $(2 \mathrm{n} / \mathrm{l})$ and sixth $(14 \mathrm{n} / \mathrm{l})$ observation. Total rotifers recorded their presence on fifth $(13 \mathrm{n} / \mathrm{l})$, sixth $(28$ $\mathrm{n} / \mathrm{l})$ and seventh $(49 \mathrm{n} / \mathrm{l})$ observation. Planaria presence was seen on fourth $(6 \mathrm{n} / \mathrm{l})$, fifth $(1 \mathrm{n} / \mathrm{l})$, sixth ( 21 $\mathrm{n} / \mathrm{l})$ and seventh $(7 \mathrm{n} / \mathrm{l})$ observation (Table 2$)$.

The study also revealed more zooplanktonic diversity and density in these pools in comparison to the observation made in the main river at Dhoomi station in the month of January (total zooplankton, $21 \mathrm{n} / \mathrm{l}$ represented by Rhizopoda only).

\section{Conclusion}

Water quality of six temporary surface rock pools on the left bank of the river Chenab at Dhoomi, Akhnoor, showed that depth, transparency, turbidity and dissolved oxygen were minimum on last observation. Whereas, temperature, conductivity, TDS, BOD, $\mathrm{pH}$, $\mathrm{CO}_{3}{ }^{-2}, \mathrm{HCO}_{3}{ }^{-}, \mathrm{Ca}^{+2}, \mathrm{Mg}^{+2}, \mathrm{TH}$ and $\mathrm{Na}^{+}$were maximum on last observation and is attributed to water evaporation and decomposition of dead organic matter by microbes. Salinity remained constant $(0.1 \mathrm{ppt})$ on all the seven observations. $\mathrm{Cl}^{-}$and $\mathrm{K}$ were noticed maximum observation on second last analysis. $\mathrm{NO}_{3}{ }^{-}, \mathrm{PO}_{4}{ }^{3^{-}}, \mathrm{SiO}_{4}{ }^{-4}$ and $\mathrm{SO}_{4}{ }^{-2}$ observed an irregular pulse in these rock pools. Fauna in these rock pools was poor and showed the presence and dominance of Protozoa (27 species) followed by Rotifera (3 species), gemmules of Porifera (2 species) and Turbellaria (1 species) only. Poor faunal diversity in these rock pools was due to shallowness, short hydroperiod, thin deposits of bottom sediments, irregular flushing and washing of rock pools by rain and river flooding, absence of aquatic vegetation and low faunal diversity in the river Chenab.

\section{ACKNOWLEDGEMENTS}

This paper is a part of the project supported by the University Grants Commission (UGC), New Delhi, and is gratefully acknowledged. Thanks are due to the authorities of https://www.researchgate.net/publication and https://onlinelibrary.wiley.com for relevant literature. I express my thanks to the HOD, Environmental Sciences, University of Jammu, Jammu, for providing necessary facilities in the department.

\section{Conflict of interests}

There is no conflict of interest regarding the publication of this article.

\section{REFERENCES}

1. Aggarwal, B. (2016). Seasonal variations of physico chemical factors and diversity of desmids (Algae) in Shahpur lake of Bhopal, India. Environmental Conservation Journal, 17(1 and 2): 67-72 
2. Alhassan, U.G. and Hazel, M.M.P. (2015). Plankton diversity, Physico- Chemical parameters and conservation value of temporary fresh water rock pools. International Journal of Research and Review, 2(9) : 562-573. https:// www.researchgate.net/publication/283033474

3. Anusa, A., Ndagurwa, H.G.T. and Magazda, C.H.D. (2012). The influence of pool size on species diversity and water chemistry in temporary rock pools on Domboshawa Mountain, North Zimbabwe. African Journal of Aquatic Science, 37(1): 89-99

4. APHA (1998) : Standard methods for examination of water and waste water. $20^{\text {th }}$ edition. American Public Health Association, New York.

5. Baskin, Y. (1994). California's ephemeral vernal pools may be a good model for speciation. BioScience, 44: 384385

6. Battish, S.K. (1992). Fresh water zooplankton of India. Oxford and IBH Publishing Company Pvt., New Delhi.

7. Bhutiani, R., Rohela, M. and Ahmed, F. (2017). Limnological characteristics of Hindon River at NCR (UttarPradesh, India). . Environmental Conservation Journal, 18(1 and 2): 219-229

8. Bratton, J.H. (1990). Seasonal pools : an overlooked invertebrate habitat. British Wildlife, 2: 22-29

9. Brendonck, L., Hamer, M.L., Riddoch, B.J. and Seaman, M.T. (2000) : Branchipodopsis species - Specialists of ephemeral rock pools. African Journal of Aquatic Science, 25: 96-104

10.Campbell, E.M. (1997). Granite landforms. Journal of the Royal Society of Western Australia, 80:101-112

11.Dutta, S.P.S. (1983). On some freshwater Rhizopoda from Jammu Part - 1. J. University Review (Science), 1: 91-94

12.Dutta, S.P.S. (2012). Limnology of the river Chenab at Akhnoor, Jammu. Part I: Water quality, Zooplankton and Fish. Project report submitted to the UGC, New, Delhi: $141 \mathrm{pp}$

13.Dutta, S.P.S. (2014). Monthly variations in physicochemical characteristics of water, MPN index and zooplankton of Devak stream, Shiv temple complex, Udhampur, Jammu (J\&K), India. Journal of Applied and Natural Science, 6(2) : 816-824

14.Edmondson, W.T. (1992). Freshwater Biology. John Wiley and Sons, New York :1248 pp

15.Ganning, B. (1971). Studies on chemical, physical and biological conditions in Swedish rockpool ecosystems. Ophelia, 9: 51-105

16.Jocque, M., Reddoch, B. and Brendonck, L. (2007). Successive phases and species replacement in freshwater rock pools with a biological definition of ephemeral water bodies. Freshwater Biology, 52:1734-1744

17.Jocque, M., Vanschoenwinkel, B. and Brendonck, L. (2010). Freshwater rock pools : a review of habitat characteristics, faunal diversity and conservation value. Freshwater Biology 55(8) : 1587-1602, (https:// doi.org/10.1111/j.1365-2427.2010.02402.x.)

18.King, J. L., Simorich, M.A. and Busca, R.C. (1996). Species richness, endemism and ecology of crustacean assemblages in Northern California vernal pools. Hydrobio- logia, 328: 85-116

19.Kudo, R.R. (1986). Protozoology. Published by Books \& Periodicals Corp. (India) : $1174 \mathrm{pp}$

20.Lane, P.A. (1978). Role of invertebrate predation in structuring zooplankton communities. Limnology, 20: 480485

21.Merlijn, J., Bram, V. and Luc, B. (2010). Freshwater rock pools: A review of habitat characteristics, fauna diversity and conservation value. Journal of Freshwater Biology, 55: $1587-1602$

22.Nair, K. N., Das, B.K. and Mukherjee, B.N. (1971). On some freshwater Rhizopoda and Helizoa (Protozoa) from Calcutta and Environments. Part 1. Rec. Zool. Surv. India. 65 (1-4): 1-16

23.Naseema, K., Masihur, R. and Khan, K.A. (2013). Study of seasonal variations in the water quality among different guards of river Ganga, Kanpur, India. Journal of Environment Research and Development 8(1): 1-10

24.Pennak, R.W. (1978). Freshwater invertebrates of the United States. $2^{\text {nd }}$ Ed. John Wiley and Sons, New York : $803 \mathrm{pp}$

25.Pinder, A.M., Halse, S.A., Shiel, R.J. and Mc Rae, J.M. (2000). Granite outcrop pools in South western Australia : foci of diversification and refugia for aquatic invertebrates. Journal of the Royal Society of Western Australia, 83: 149 $-161$

26.Reid, G.K. and Wood, R.D. (1976). Ecology of inland waters and estuaries. D.Van Norstand Company, New York : $485 \mathrm{pp}$

27.Shinde, Y. and Kulkarni, M. (2020). Rock pools that support unique ecosystems need conservation in Pune. Times of India. March 9, 2020. (https:// www.m.timesofindia.com/city/pune/rock-pools-thatsupport-unique-ecosystems-need-conservation/ amp_articleshow/74542477.cms)

28.Scholnick, D.A. (1994). Seasonal variation and diurnal fluctuations in ephemeral desert pools. Hydrobiologia, 294: 111-116

29. Tavernini, S. (2008). Seasonal and inter-annual zooplankton dynamics in temporary pools with different hydroperiods. Limnologica-ecology and Management of Inland Waters, 38(1) : 63-75

30.Trivedi, R. K., Goel, P. K. and Trisal, C.L. (1987). Practical methods in ecology and environmental science. Environmental Publ., Kard, India.

31.Vanschoenwinkel, B., Hulsmans, A., De Roecks, E.R., De Vries, C., Seaman, M. and Brendonck, L. (2009): Community structure in temporary freshwater rock pools: disentangling effects of habitat size and hydro regime and the impact of dispersal mode. Freshwater Biology, 54: 14871500

32.Welch, P.S. (1952). Limnology. McGraw Hill Book Company Inc., New York: 539 pp

33.Wetzel, R.G. (2000). Limnology : Lake and river ecosystems. $3^{\text {rd }}$ edition. Academic Press, London.

34.Williams, D.D. (1997).Temporary ponds and their invertebrate communities. Aquatic Conservation: Marine and Freshwater Ecosystems, 7: 105-117 